\title{
The Government Deficit and the Long-Term Interest Rate: Application of an Extended Loanable Funds Model to Sweden
}

\author{
Yu Hsing \\ Department of Management \& Business Administration \\ College of Business, Southeastern Louisiana University \\ Hammond, LA 70402, USA \\ Tel: 985-549-2081Ｅ-mail: yhsing@selu.edu
}

Received: January 15, 2010

Accepted: July 21, 2010

doi:10.5539/ijef.v3n3p84

\begin{abstract}
Applying and extending the open-economy loanable funds model, this paper finds that more government deficit as a percent of GDP leads to a higher government bond yield and that a higher real Treasury bill rate, a smaller percent change in real GDP, a higher expected inflation rate, a higher U.S. government bond yield, or depreciation of the Swedish krona (SEK) against the euro would increase the Swedish government bond yield. When the standard closed-economy or open-economy loanable funds model is considered, we find similar conclusions for the ratio of the government deficit to GDP, the real Treasury bill rate, and the expected inflation rate whereas the negative coefficient of the percent change in real GDP or the ratio of the net capital inflow to GDP is insignificant at the 10\% level. Hence, the incorporation of the world long-term interest rate and the exchange rate would better capture the behavior of the Swedish government bond yield.
\end{abstract}

Keywords: Government deficits, Long-term interest rates, Expected inflation, World interest rates, Exchange rates, Loanable funds model

\section{Introduction}

The recent worldwide recession has led many countries to experience declining business and economic activities and budget concerns. Sweden is no exception. According to the International Financial Statistics and the "Economic and Financial Data for Sweden" in the Dissemination Standards Bulletin Board (DSBB) published by the International Monetary Fund (2009), Sweden's real GDP declined 6.6\% during 2008.Q2 - 2009.Q2, industrial production dropped 20.9\% during August 2008 - August 2009, and the central government budget changed from a large surplus of 105.5 billion SEK to a large deficit of 88.4 billion SEK during 2008.Q3 - 2009.Q2.

There has been a renewed interest in examining whether more government deficit would raise the long-term interest rate, crowd out some of private investment expenditures, and hinder economic growth. Previous studies suggest that the interest rate may or may not respond to more government deficit. Feldstein (1982), Hoelscher (1986), Wachtel and Young (1987), Zahid (1988), Thomas and Abderrozak (1988), Miller and Russek (1991), Raynold (1994), Cebula (1989, 1991, 1993, 1997, 1999, 2003), Vamvoukas (1997), Ewing and Yanochik (1999), and Saleh and Harvie (2005) hold the view that there is a positive impact of the government deficit on the interest rate. Kormendi (1983), Hoelscher (1983), Aschauer (1985), Makin (1983), McMillin (1986), Barro (1987), Evans (1985, 1987, 1988), Gupta (1989), Darrat (1989, 1990), Findlay (1990), and Ostrosky (1990) maintain the opinion that more government deficit would not raise the interest rate.

In a recent article, Hartman (2007) shows that results for the effect of government deficits on interest rates are inconclusive because there is some support for the crowding-out hypothesis whereas crowding-in may overwhelm in the short run. He also indicates that an expected increase in future deficits could raise today's real interest rates. Barnes (2008) examines the subject for ten advanced Western countries and finds that each of the countries exhibits several cointegrating vectors and that more government budget deficits cause long-term interest rates to rise. Wang and Rettenmaier (2008) indicate that impacts of government deficits on interest rates are positive, may last up to 8 years, are not permanent, and will die out after 8 years. These previous studies have made significant contributions to the formulation of the models, test of the hypotheses, and interpretation of the results.

This paper attempts to examine the impact of the government deficit on the long-term interest rate for Sweden and has several focuses. First, the model is extended to incorporate the world interest rate and the exchange rate as potential variables explaining the behavior of international capital flows in supplying loanable funds. Second, comparative-static analysis is applied to determine the theoretical sign of a change in one of the exogenous variables 
on the equilibrium long-term interest rate. Third, the latest available data are employed in empirical work, and the results would have more policy implications. The paper is organized in the following manner. The theoretical model is presented in the next section. Data sources, the definition and measurement of variables, and empirical results are described and analyzed in the third section. The summary and conclusions are made in the last section.

\section{The Model}

The loanable funds model has been employed in studying the impact of government deficits on interest rates (Hoelscher, 1986; Tran and Sawhney, 1988; Thomas and Abderrezak, 1988; Cebula, 1988, 1994, 1997a, 1997b, 1998, 1999, 2000, 2003, 2005; Correia-Nunes and Stemitsiotis, 1995; García and Ramajo, 2004; Quayes and Jamal, 2007; Barnes, 2008). Hoelscher (1986) develops a closed-economy loanable funds model, and Cebula (1988, 1994, 1997a, 1997b, 1998, 1999, 2000, 2003) proposes an open-economy loanable funds model by considering the net capital inflow in the supply of loanable funds.

In this paper, the behavior of the net capital inflow is explained by the relative interest rate and the exchange rate (Devereux and Saito, 2006; De Santis and Luhrmann, 2009). As the world long-term interest rate rises relative to the Swedish long-term interest rate, the net capital inflow to Sweden would decrease. As the Swedish krona depreciates relative to other currencies, the net capital inflow to Sweden would decrease. Hence, a higher world interest rate would shift the supply of loanable funds to the left and increase the Swedish long-term interest rate, and a depreciation of the Swedish krona would shift the supply of loanable funds to the left and increase the Swedish long-term interest rate. Suppose the demand for loanable funds is negatively affected by the long-term interest rate and positively influenced by the real short-term interest rate, the expected inflation rate, the percent change in real GDP, and the government deficit and that the supply of loanable funds is positively associated with the long-term interest rate and the percent change in real GDP and negatively associated with the real short-term interest rate, the expected inflation rate, the world interest rate, and the depreciation of the Swedish krona. Thus, in the extended open-economy loanable funds model, the demand for and the supply of loanable funds can be expressed as

$$
\begin{array}{r}
D=D(L R, S R, E I, G Y, B D) \\
S=S(L R, S R, E I, G Y, W R, E X)
\end{array}
$$

where

$$
\begin{aligned}
& \mathrm{D} \quad=\text { the demand for loanable funds in Sweden, } \\
& \mathrm{S} \quad=\text { the supply of loanable funds in Sweden, } \\
& \mathrm{LR} \quad \text { = the long-term interest rate in Sweden, } \\
& \mathrm{SR} \quad=\text { the real short-term interest rate in Sweden, } \\
& \mathrm{EI} \quad=\text { the expected inflation rate in Sweden, } \\
& \mathrm{GY}=\text { percent change in real GDP in Sweden, } \\
& \mathrm{BD} \quad=\text { the government deficit in Sweden, } \\
& \text { WR = the world long-term interest rate, and } \\
& \text { EX = the exchange rate measured as the SEK per unit of a foreign currency. (An increase means }
\end{aligned}
$$

Setting D and S equal to the equilibrium loanable funds $(L F)$, we can write the equilibrium long-term interest rate as

$$
\overline{L R}=\overline{L R}(B D, S R, G Y, E I, W R, E X)
$$

The partial derivative of $\overline{L R}$ with respect to each of the exogenous variables is given by

$$
\begin{gathered}
\partial \overline{L R} / \partial B D=D_{B D} /|J|>0 \\
\partial \overline{L R} / \partial S R=\left(D_{S R}-S_{S R}\right) /|J|>0 \\
\partial \overline{L R} / \partial G Y=\left(D_{G Y}-S_{G Y}\right) /|J|>\text { or }<0 \\
\partial \overline{L R} / \partial E I=\left(D_{E I}-S_{E I}\right) /|J|>0 \\
\partial \overline{L R} / \partial W R=-S_{W R}|J|>0
\end{gathered}
$$




$$
\partial \overline{L R} / \partial E X=-S_{E X} /|J|>0
$$

where $|J|$ is the Jacobian for the endogenous variables and has a positive value. Theoretically, the equilibrium long-term interest rate has a positive relationship with the government deficit, the real short-term interest rate, the expected inflation rate, the world long-term interest rate, or the exchange rate, and the sign of the partial derivative of the equilibrium long-term interest rate with respect to the percent change in real GDP is unclear.

In comparison, the equilibrium long-term interest rate in the standard closed-economy loanable funds model (Hoelscher, 1986) can be written as

$$
\overline{L R}=\overline{L R}(B D, S R, G Y, E I)
$$

The equilibrium long-term interest rate in the standard open-economy loanable funds model (Cebula, 1988, 1994, 1997a, 1997b, 1998, 1999, 2000, 2003) is given by

$$
\overline{L R}=\overline{L R}(B D, S R, G Y, E I, C F)
$$

where CF is the net capital inflow. The sign of CF should be negative as an increase in the net capital inflow to Sweden would shift the supply of loanable funds to the right and reduce the equilibrium long-term interest rate.

\section{Empirical Results}

The data were collected from the International Financial Statistics, which is published by the International Monetary Fund. The dependent variable is the Swedish government bond yield. The real short-term interest rate is represented by the real 3-month Treasury bill rate in Sweden to test for a potential substitution effect. The expected inflation rate is estimated by the average inflation rate of the past four quarters. GY is represented by the percent change in real GDP. BD is measured by the ratio of the government deficit to GDP. The 10-year U.S. government bond yield is chosen to represent the world interest rate. EX is represented by the SEK/EUR exchange rate. An increase in the exchange rate means depreciation of the Swedish krona against the euro. CF is measured by the ratio of the net capital inflow to GDP, where the net capital inflow is the sum of the portfolio, direct and other investments in the financial account. The sample ranges from 1994.Q1-2009.Q1 for equations (3) and (10) and from 1994.Q1 to 2008.Q4 for equation (11).

The unit root test shows that each of the variables has a unit root in the level form and is stationary in first difference. As shown in Table 1, based on the unrestricted cointegration rank test, there are 2 cointegrating equations. Therefore, there is a long-term stable relationship among the variables.

Table 2 plots the residual histogram and presents the normality test for the error terms. As shown, the Jarque-Bera statistic of 1.37 is much smaller than the critical value of 9.21 at the $1 \%$ level or 5.99 at the $5 \%$ level. Hence, the null hypothesis of a normal distribution of the error terms cannot be rejected. According to the serial correlation LM test with 2 lags, the $F$ test statistic is 24.21 , and the critical value with $F(2,52)$ is 4.98 at the $1 \%$ level. Thus, the lack of serial correlation can be rejected. Based on the White heteroskedasticity test, the F test statistic is 3.15 , and the critical value with $\mathrm{F}(12,48)$ is 2.66 at the $1 \%$ level. Hence, the lack of heteroskedasticity can be rejected.

Table 3 reports the estimated regression and related statistics. Due to the simultaneous existence of serial correlation and heteroskedasticity, the Newey-West (1987) GLS method is applied in order to yield consistent estimates for the covariance and standard errors when their forms are unknown and to make sure that hypothesis tests are valid. As shown, $93.6 \%$ of the variation in the government bond yield can be explained by the six right-hand side variables. All the coefficients are significant at the $1 \%$ or $5 \%$ level. The government bond yield is positively associated with the ratio of the government deficit to GDP, the real Treasury bill rate, the expected inflation rate, the U.S. government bond yield, and the SEK/EUR exchange rate, and it is negatively influenced by the percent change in real GDP.

The VECM is estimated. Based on the lag exclusion test, the lag length of one is chosen. The results show that the coefficients of the lagged LR, GY, and EI are significant at the different levels, that the coefficients of BD, SR, WR, and EX are insignificant at the $10 \%$ level, and that the coefficient of the error correction term is significant at the 5\% level. In comparison, the results in Table 3 are better than those in the VECM model.

Several different measures of the variables are considered to determine whether the outcomes may vary. If the ratio of the government deficit to GDP is replaced by the ratio of the government borrowing to GDP, its positive coefficient is significant at the $1 \%$ level, the coefficient of the SEK/EUR exchange rate is negative and insignificant at the $10 \%$ level, and other results are similar. If the SEK/EUR exchange rate is replaced by the SEK/USD exchange rate, its coefficient is negative and insignificant at the $10 \%$ level, and other results are similar. It suggests that the selection of the SEK/EUR exchange rate in empirical work is more appropriate as Sweden is obliged to join the euro 
zone and is required to maintain a relatively stable exchange rate with the euro. To save space, details are not printed here and will be available upon request.

When the standard closed-economy loanable funds model in equation (10) is considered in empirical work, the value of the adjusted R-squared is 0.882 , and the sign and significance of the coefficients for BD, SR, and EI are similar to those reported in Table 3 whereas the negative coefficient of GY is insignificant at the $10 \%$ level. When the standard open-economy loanable funds model in equation (11) is considered, the value of the adjusted R-squared is 0.885 , the negative coefficients of GY and CF are insignificant at the $10 \%$ level, and other results are similar to the findings in the standard closed-economy loanable funds model. Hence, the inclusion of the world long-term interest rate and the exchange rate would improve the explanatory power of the regression and better capture the behavior of international capital flows.

\section{Summary and Conclusions}

This paper has applied an extended open-economy loanable funds model to examine whether the Swedish long-term interest rate would be affected by the government deficit and other selected macroeconomic variables. The results show that more government deficit would raise the government bond yield and that a higher real Treasury bill rate, a smaller percent change in real GDP, a higher expected inflation rate, a higher U.S. government bond yield, and a higher SEK/EUR exchange rate (depreciation of the SEK) would raise the Swedish government bond yield. In the standard closed-economy loanable funds model, except that the negative coefficient of the percent change in real GDP is insignificant at the $10 \%$ level, similar results are found. In the standard open-economy loanable funds model, except that the negative coefficients of the percent change in real GDP and the ratio of the net capital inflow to GDP are insignificant at the $10 \%$ level, other results are similar to those reported in Table 3 for the extended open-economy loanable funds model. Hence, the world long-term interest rate and the SEK/EUR exchange rate incorporated in this study increase the explanatory power for the behavior of the Swedish government bond yield.

There are several policy implications. The significant coefficient of the ratio of the government deficit to GDP implies that pursing deficit-financed expansionary fiscal policy to stimulate the economy would raise the long-term government bond yield and crowd out part of private spending. It suggests that the multiplier effect of increased government deficit spending would be smaller than the case with an insignificant coefficient for the ratio of the government deficit to GDP. In the open-economy loanable funds model, the world interest rate and the exchange rate need to be considered as international investors search for better returns in determining the supply of loanable funds to Sweden or other countries. The insignificant negative coefficient of the ratio of the net capital inflow to GDP suggests that its role in affecting loanable funds may need to be further studied.

There may be potential areas for future research. After the global recession, the regressions may be re-estimated to determine whether the results may change. The expected inflation rate may be constructed by other methodologies. Other theories of interest rate determination such as the IS-LM model may be considered, although there are issues and problems in applying the model (Romer, 2000).

\section{References}

Aschauer, D. A. (1989). Does public capital crowd out private capital? Journal of Monetary Economics, 25, 171-88.

Barnes, B. J. (2008). A Cointegrating approach to budget deficits and long-term interest rates, Applied Economics, 40, 127-33.

Barro, R. J. (1974). Are government bonds net wealth, Journal of Political Economy, 82, 1095-117.

Barro, R. J. (1987). Government spending, interest rates, prices, and budget deficits in the United Kingdom, 1701-1918, Journal of Monetary Economics, 20, 221-47.

Barro, R. (1989). The Ricardian approach to budget deficits, Journal of Economic Perspectives, 3, 37-54.

Barth, J. R., Iden, G. R., and Russek, F. S. (1984). Do federal budget deficits really matter? Contemporary Policy Issues, 3, 79-95.

Barth, J. R., Iden, G. R., and Russek, F. S. (1985). Federal borrowing and short-term interest rates: comment, Southern Economic Journal, 52, 554-9.

Bovenberg, A. L. (1988). Long-term interest rates in the US, International Monetary Fund Staff Papers, 35, 382-90.

Cebula, R. J. (1988). Federal government budget deficits and interest rates: an analysis for the United States 1955-1984, Public Finance, 43, 337-48.

Cebula, R. J. (1991). A note on federal budget deficits and the term structure of real interest rates in the United

States, Southern Economic Journal, 57, 1170-3. 
Cebula, R. J. (1997). The impact of net international capital flows on nominal long-term interest rates in France, Southern Economic Journal, 25, 179-90.

Cebula, R. J. (1998). Budget deficits and long-term interest rates: 1973-1991, International Advances in Economic Research, 4, 374-88.

Cebula, R. J. (1999). Budget deficits, capital flows, and long-term interest rates: cointegration findings for the UK, International Advances in Economic Research, 5, 374-88.

Cebula, R. J. (2003). Budget deficits and interest rates in Germany, International-Advance in Economic Research, 9 , 64-8.

Cebula, R. J. and Belton, W. J. (1993). Government budget deficits and interest rates in the United States: evidence for closed and open systems put into perspective, 1955-1989, Public Finance, 48, 188-209.

Cebula, R. J. and Koch, J. V. (1989). An empirical note an deficits, interest rates, and international capital flows, Quarterly Review of Economics and Business, 29, 121-7.

Cebula, R. J. and Saltz, I. S. (1992). Central government budget deficits and ex ante real long term interest rates in the United Kingdom: an empirical note, International Review of Economics and Business, 39, 479-84.

Darrat, A. F. (1989). Fiscal deficits and long-term interest rates: further evidence from annual data, Southern Economic Journal, 56, 363-73.

Darrat, A. F. (1990). Structural federal deficits and interest rates: some causality and cointegration tests, Southern Economic Journal, 56, 752-9.

De Santis, R. A. and Luhrmann, M. (2009). On the determinants of net international portfolio flows: a global perspective, Journal of International Money and Finance, 28, 880-901.

Devereux, M. B. and Saito, M. (2006). A portfolio theory of international capital flows, CEPR Discussion Papers: 5746.

Evans. P. (1985). Do large deficits produce high interest rates? American Economic Review, 75, 68-87.

Evans, P. (1987). Do budget deficits raise nominal interest rates? evidence from six countries, Journal of Monetary Economics, 20, 281-300.

Evans. P. (1988). Are government bonds net wealth? evidence for the United States, Economic Inquiry, 26, 551-66.

Ewing, B. T. and Yanochik, M. A. (1999). Budget deficits and the term structure of interest rates in Italy, Applied Economics Letters, 6, 199-201.

Feldstein, M. (1982). Government deficits and aggregate demand, Journal of Monetary Economics, 9, 1-20.

Findlay, D. W. (1990). Budget deficits, expected inflation and short-term real interest rates: evidence for the US, International Economic Journal, 4, 41-53.

Gupta, K. L. (1989). Budget deficits and interest rates in the US, Public Choice, 60, 87-92.

Hartman, H. C. (2007). Deficit-related explanations for the US interest rate conundrum, Applied Economics Letters, 14, 261-5.

Hoelscher, G. (1983). Federal borrowing and short-term interest rates, Southern Economic Journal, 50, 319-33.

Hoelscher, G. (1986). New evidence on deficits and interest rates, Journal of Money, Credit, and Banking, 18, 1-17.

Johansen, S. (1988). Statistical analysis of cointegration vectors, Journal of Economic Dynamics and Control, 12, 231-54.

Kormendi, R. C. (1983). Government debt, government spending, and private sector behaviour, American Economic Review, 73, 994-1010.

Makin, J. H. (1983). Real interest, money surprises, anticipated inflation and fiscal deficits, Review of Economics and Statistics, 65, 374-84.

McMillan, W. D. (1986). Federal deficits and short-term interest rates, Journal of Macroeconomics, 8, 403-22.

Miller. S. M., and Russek, Jr., F. S. (1991). The temporal causality between fiscal deficits and interest rates, Contemporary Policy Issues, 9, 12-23.

Newey, W. K., and West, K. D. (1987). A simple, positive semi-definite, heteroskedasticity and autocorrelation consistent covariance matrix, Econometrica, 55, 703-708.

Ostrosky, A. L. (1990). Federal government budget deficits and interest rates: comment, Southern Economic Journal, 56, 802-3. 
Raynold, P. (1994). The impact of government deficits when credit markets are imperfect: evidence from the interwar period. Journal of Macroeconomics, 16, 55-76.

Romer, D. (2000). Keynesian macroeconomics without the LM curve, Journal of Economic Perspectives, 14, 149-60.

Saleh, A. S. and Harvie, C. (2005). The budget deficit and economic performance: a survey, Singapore Economic Review, 50, 211-43.

Thomas Jr. L. B. and Abderrezak, A. (1988). Long-term interest rates: the role of expected budget deficits, Public Finance Quarterly, 1, 341-56.

Tran, D. T. and Sawhney, B. L. (1988). Government deficits, capital flows, and interest rates, Applied Economics, 20,753-765.

Vamvoukas, G. A. (1997). A note on budget deficits and interest rates: evidence from a small, open economy, Southern Economic Journal, 63, 803-11.

Wachtel, P. and Young, J. (1987). Deficit announcements and interest rates, American Economic Review, 5, $1007-12$.

Wang, Z. and Rettenmaier, A. J. (2008). Deficits, explicit debt, implicit debt, and interest rates: some empirical evidence, Southern Economic Journal, 75, 208-22.

Zahid, K. H. (1988). Government budget deficits and interest rates: the evidence since 1971 using alternate deficit measures, Southern Economic Journal, 3, 725-31.

Table 1. Unrestricted Cointegration Rank Test (Maximum Eigenvalue)

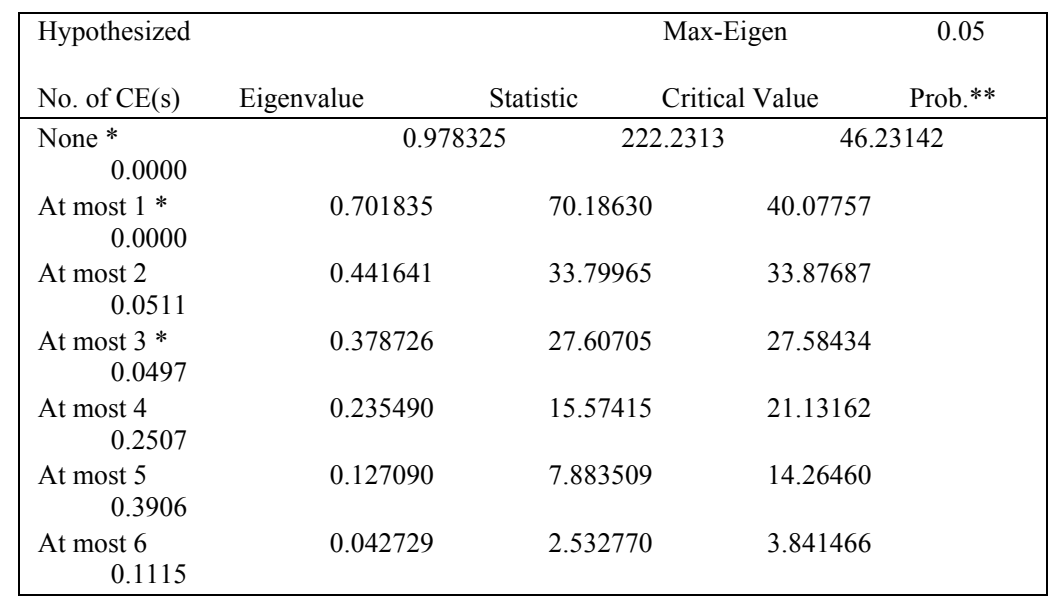

Notes:Max-eigenvalue test indicates 2 cointegrating equations at the $5 \%$ level.

* denotes rejection of the hypothesis at the 0.05 level

**MacKinnon-Haug-Michelis (1999) p-values

Table 2. The Jargue-Bera Normality Test of the Regression Residuals

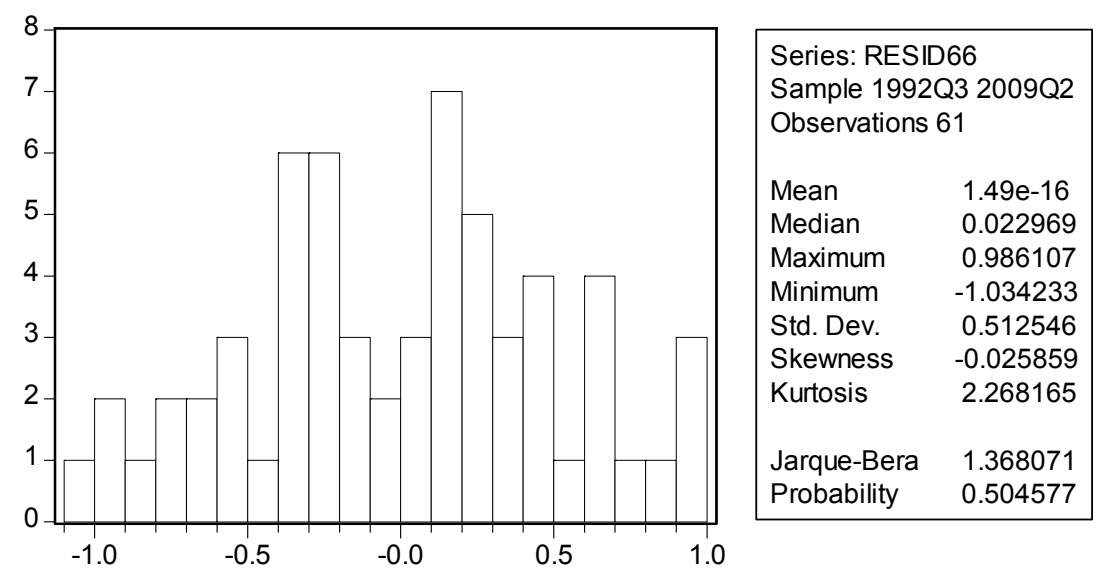


Table 3. Estimated Regression of the Government Bond Yield (LR) for Sweden based on the Extended Loanable Funds Model

\begin{tabular}{|lcccc|}
\hline Variable & Coefficient & Std. Error & t-Statistic & Prob. \\
\hline C & -7.489969 & 3.122322 & -2.398846 & 0.0199 \\
BD & 0.043400 & 0.018516 & 2.343911 & 0.0228 \\
SR & 0.625743 & 0.091479 & 6.840326 & 0.0000 \\
GY & -0.008206 & 0.004002 & -2.050235 & 0.0452 \\
EI & 2.253477 & 0.375125 & 6.007267 & 0.0000 \\
WR & 0.903354 & 0.157348 & 5.741107 & 0.0000 \\
EX & 0.652753 & 0.291986 & 2.235565 & 0.0295 \\
& & & & \\
R-squared & & 0.942621 & & \\
Adjusted R-squared & & 0.936246 & & \\
Akaike info criterion & & 1.714127 & & \\
Schwarz criterion & & 1.956358 & & \\
Log likelihood & -45.28087 & & \\
F-statistic & 147.8527 & & \\
Prob(F-statistic) & 0.000000 & & \\
Sample period & $1994 . \mathrm{Q} 1-$ & \\
& & $2009 . \mathrm{Q} 1$ & & \\
N & 61 & & \\
\hline
\end{tabular}

Notes:

The Newey-West method is employed to yield consistent estimates for the covariance and standard errors. $\mathrm{C}$ is the constant. BD is the ratio of the government deficit to GDP. SR is the real Treasury bill rate. GY is the percent change in real GDP. EI is the expected inflation rate. WR is the 10 -year U.S. government bond yield. EX is the SEK/EUR exchange rate. 